\title{
Operators' Evaluation and Allocation in SME's Food Manufacturing Company Using Analytical Hierarchy Process and Computer Simulation
}

\author{
Ruzanita Mat Rani, Wan Rosmanira Ismail, and Mohd Nizam Ab. Rahman
}

\begin{abstract}
This paper presents the applications of Analytical Hierarchy Process (AHP) and computer simulation within the context of operators' evaluation and allocation. AHP can be used to evaluate the performance of operators while computer simulation can be applied in analyzing the impact of production system performance if the operators' performance is included in the operator allocation decision. The combination of the methods used in this study, improve the flexibility of the operator allocation decision. The results of the study are compared. It is found that operator allocation decision with the consideration of operators' performance will affect the performance of the production system and outperform the current operator allocation decision.
\end{abstract}

Index Terms-AHP, computer simulation, operator allocation.

\section{INTRODUCTION}

The manufacturing sector in Malaysia is rapidly growing and becoming one of the main contributors to the country's gross domestic product (GDP) [1]. This environment has created competition among manufacturing companies where many companies produced similar products. Therefore, to ensure that these companies can compete in a way that can generate more profit, the management of the company should take various initiatives especially in managing the resources. One of the important resources is operators. The operator is a person who controls the process in the production system. In the production system, the operator allocation decision is important because it will affect the throughput and cost. The operator allocation decision is related to "who works where?" [2]. Bad decisions in operator allocation will result in lower productivity and increase the operating costs [3].

In previous studies [4]-[6], the operator allocation decision is to determine the number of operators that should be allocated in each process with the assumption of all operators have the same performance level.

Manuscript received February 19, 2014; revised April 22, 2014. The research work is supported by Universiti Teknologi MARA, Shah Alam, Selangor and Ministry of Higher Education, Malaysia.

Ruzanita Mat Rani is with the Centre for Statistical and Decision Sciences Studies, Faculty of Computer and Mathematical Sciences, Universiti Teknologi MARA, 40450 Shah Alam, Selangor, Malaysia (e-mail: ruzanita@tmsk.uitm.edu.my).

Wan Rosmanira Ismail is with the School of Mathematical Sciences, Faculty of Science and Technology, Universiti Kebangsaan Malaysia, 43600 UKM Bangi, Selangor, Malaysia (e-mail: wrismail@ukm.my).

Mohd Nizam Ab. Rahman is with the Department of Mechanical and Materials Engineering, Faculty of Engineering \& Built Environment, Universiti Kebangsaan Malaysia, 43600 UKM Bangi, Selangor, Malaysia (e-mail: mnizam@eng.ukm.my).
For example, to determine the most efficient number of operators in a cellular manufacturing system, simulation and Data Envelopment Analysis (DEA) is applied [4], to ascertain the optimal staffing level of a labor-intensive manufacturing system by applying simulation, Analytical Hierarchy Process (AHP), TOPSIS and fuzzy-based logic [5] and fuzzy-DEA, fuzzy C-means and simulation are used to identify the optimal operator allocation [6].

Given that human involvement is important in the production system, especially in labor-intensive manufacturing system, the performance of operators should not be taken for granted in operator allocation decision. Different operators' performance will result in different production systems' performance [2]. Fuzzy set theory and MILP are applied to evaluate and allocate the operators in three factories [2]. Fuzzy AHP, max-min approach and non-parametric statistical test had been used to evaluate and to allocate the operators at one of the electronics companies in Turkey [7]. Previous studies [2], [7] had identified that operator performance influence the performance of the production system.

Therefore, in this study different approaches will be used in evaluating and allocating the operators. Real applications in operators' evaluation and allocation in one of the SMEs food manufacturing companies was performed in order to demonstrate the relevance of the methods used.

\section{MATERIAL AND MethodS}

The study is carried out in two phases. The first phase is to evaluate the performance of operators using AHP. Then, the allocation of operator to each process will be done according to the operators' performance score. In the second phase, computer simulation will assist in generating output for different types of operator allocation models.

\section{A. Operators Evaluation}

The operator performance evaluation is one of the key strategies in strengthening the productivity of a company. The company will assess the achievement level of their operators at a certain period of time through operator performance evaluation. The efficient and systematic performance evaluation will give benefit to the operators and the management of the company. The purpose of the operator performance evaluation is to provide feedback on operators' work performance, to identify the strengths and weaknesses of each operator and to suggest steps to be taken by the operators and the management of the company in order to improve the performance of operators. 
Multi criteria decision making methods can be applied to evaluate the performance of the operator. AHP is one of the multi criteria decision making methods that has been developed by Saaty [8]. This method is well known and often becomes a tool to solve multi criteria decision making problem. For example, AHP is used to evaluate the performance of 25 employees at Inter System Maintenance Sdn. Bhd. [9]. This company specialized in maintenance and cleaning services. At GY Company who produced small furniture, fuzzy AHP is used to evaluate 50 workers [10]. Fuzzy AHP also had been applied to solve personnel selection problem [11]. The AHP procedure is given in the following steps.

1) Develop a hierarchy, at the top level is the overall objective and at the subsequent levels are criteria, sub-criteria and the alternatives. The AHP hierarchy is shown in Fig. 1.

2) The matrix of pairwise comparison is constructed based on the Saaty scale. Saaty scale is shown in Table I. Pairwise comparison is done for criteria, sub-criteria and alternatives in the AHP hierarchy, respectively. The objective is to determine the priorities of different criteria and sub-criteria and then choose the best alternative.

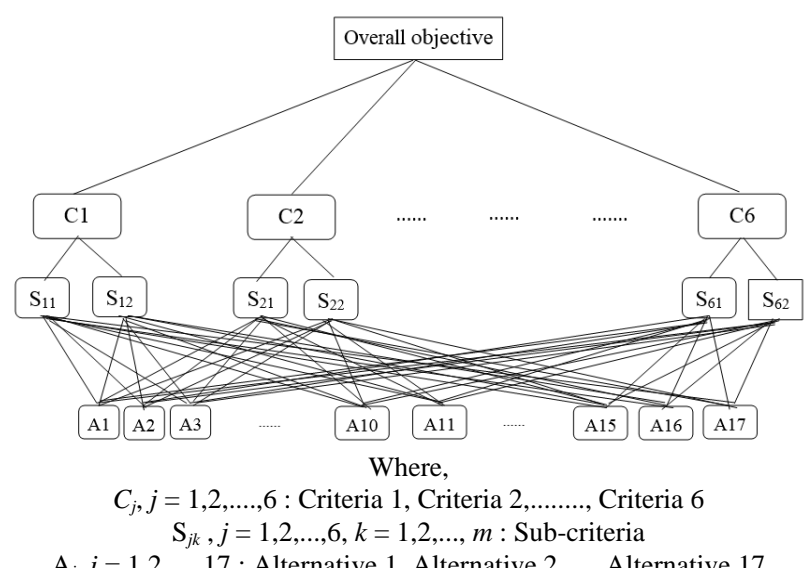

$\mathrm{A}_{i}, i=1,2, \ldots ., 17$ : Alternative 1, Alternative 2,...., Alternative 17

Fig. 1. AHP hierarchy.

TABLE I: SAATY SCALE FOR PAIRWISE COMPARISON

\begin{tabular}{|c|l|}
\hline Numerical value & Verbal scale \\
\hline 1 & Equal importance \\
\hline 3 & Moderate importance \\
\hline 5 & Strong importance \\
\hline 7 & Very strong importance \\
\hline 9 & Extreme importance \\
\hline $2,4,6,8$ & Intermediate values \\
\hline
\end{tabular}

3) AHP also calculates the consistency index (CI) for each pairwise comparison matrix to describe the consistency of decision making during the evaluation process. $C I$ can be calculated using the following equation:

$$
C I=\frac{\lambda_{\max }-N}{N-1}
$$

$\lambda_{\max }$ is the maximum eigenvalue and $N$ is the number of items being compared. The consistency ratio $(C R)$ can be calculated using the following equation:

$$
C R=\frac{C I}{R I}
$$

$R I$ is Random Index [12] and shown in Table II.

The value of $C R$ must be less than or equal to 0.10 to obtain a consistent pairwise comparison matrix and it will then be accepted. If the value of $C R$ is greater than 0.10 , the evaluation process should be repeated because the pairwise comparison matrix is inconsistent.

4) The weights of criteria, sub-criteria and alternatives are computed. The overall score of each alternative can be calculated using the following equation:

$$
w_{A_{l}}=\sum_{j=1}^{6} w_{c_{j}} \sum_{k=1}^{m} w_{s_{j k}} w_{s_{j k A_{l}}}
$$

$w_{A_{l}}$ is the weight of $l^{\text {th }}$ alternative, $w_{c_{j}}$ is the weight of $j^{\text {th }}$ criteria, $w_{s_{j k}}$ is the weight of $k^{\text {th }}$ sub-criteria related to $j^{\text {th }}$ criteria and $w_{s_{j k A l}}$ is the weight of $l^{\text {th }}$ alternative related to $k^{\text {th }}$ sub-criteria and $j^{\text {th }}$ criteria. An alternative with the largest $w_{A_{l}}$ score lies in the first rank. The AHP procedure can be performed using Expert Choice software [13].

In this study, 17 alternatives (operators) are involved, six criteria $(j=1, \ldots, 6)$ and $m$ sub-criteria under each criteria $(k=$ $1, \ldots, m)$ are selected. The selected criteria are based on previous studies [2], [7], [9]-[11], [14]-[17] and they are approved by the management of the company. Criteria that have been selected are competency, experience and skill, teamwork and time punctuality, personal characteristics, outcome and capability. Competence refers to the ability of an operator to do the job efficiently. There are two sub-criteria related to competency which are training and educational background. Experience and skill are related to knowledge gained by an operator through experienced and cleverness of an operator to do the task given. Past experience in other company and experience in the company are the experience and skill sub-criteria. Teamwork and timing punctuality are cooperation given by an operator in doing work together and the ability of an operator can complete the task given within the specified time. The sub-criteria associated with teamwork and time punctuality are teamwork and time punctuality. The personal characteristics are the nature or attitude of an operator. Three sub-criteria related to personal characteristics are attendance, level of adaptation to change and the degree of loyalty and honesty. Outcome refers to the final results of the production. Quality and quantity of work are the sub-criteria associated with outcome. Finally, capability is the willingness and the ability of an operator to do the task given. There are two sub-criteria related to capability which are working ability and communication ability.

Next step is to determine the weights of criteria, sub-criteria and alternatives. To determine weights, the supervisor of the company needs to evaluate and construct a pairwise comparison matrix based on Saaty scale (refer to Table I). The matrices of pairwise comparison are given in Table III -Table IX. The $C R$ of each pairwise comparison matrix was calculated using (1) and (2). The $C R$ for Table III - IX are 0.077, 0.000, 0.000, 0.000, 0.028, 0.000 and 0.000, respectively. All $C R$ s are less than 0.10 which means that all pairwise comparison matrices are consistent and accepted. 
TABLE II: RANDOM INDEX

\begin{tabular}{|l|l|l|l|l|c|c|c|c|c|c|}
\hline$N$ & 1 & 2 & 3 & 4 & 5 & 6 & 7 & 8 & 9 \\
\hline$R I$ & 0 & 0 & 0.52 & 0.89 & 1.11 & 1.25 & 1.35 & 1.40 & 1.45 & 1.49 \\
\hline
\end{tabular}

TABLE III: THE PAIRWISE COMPARISON MATRIX FOR CRITERIA

\begin{tabular}{|c|c|c|c|c|c|c|c|}
\hline & Competency & $\begin{array}{c}\text { Experience } \\
\text { and } \\
\text { skill }\end{array}$ & $\begin{array}{c}\text { Teamwork and time } \\
\text { punctuality }\end{array}$ & $\begin{array}{c}\text { Personal } \\
\text { characteristics }\end{array}$ & Outcome & Capability & Weights \\
\hline Competency & 1 & $1 / 4$ & $1 / 5$ & $1 / 5$ & $1 / 7$ & $1 / 5$ & 0.031 \\
\hline Experience and skill & 4 & 1 & $1 / 5$ & $1 / 5$ & $1 / 7$ & $1 / 5$ & 0.052 \\
\hline $\begin{array}{c}\text { Teamwork and time } \\
\text { punctuality }\end{array}$ & 5 & 5 & 1 & 1 & $1 / 2$ & 1 & 0.173 \\
\hline Personal characteristics & 5 & 5 & 1 & 1 & $1 / 4$ & 2 & 0.178 \\
\hline Outcome & 7 & 7 & 2 & 4 & 1 & 5 & 0.427 \\
\hline Capability & 5 & 5 & 1 & $1 / 2$ & $1 / 5$ & 1 & 0.139 \\
\hline
\end{tabular}

TABLE IV: THE PAIRWISE COMPARISON MATRIX FOR COMPETENCY SUB-CRITERIA

\begin{tabular}{|c|c|c|c|}
\hline & Training & $\begin{array}{l}\text { Educational } \\
\text { background }\end{array}$ & Weights \\
\hline Training & 1 & $1 / 7$ & 0.125 \\
\hline $\begin{array}{c}\text { Educational } \\
\text { background }\end{array}$ & 7 & 1 & 0.875 \\
\hline
\end{tabular}

TABLE V: THE PAIRWISE COMPARISON MATRIX FOR EXPERIENCE AND SKILL SUB-CRITERIA

\begin{tabular}{|c|c|c|c|}
\hline & $\begin{array}{c}\text { Past experience in } \\
\text { other company and } \\
\text { experience in the } \\
\text { company }\end{array}$ & Skill & Weights \\
\hline $\begin{array}{c}\text { Past experience in other } \\
\text { company and experience } \\
\text { in the company }\end{array}$ & 1 & $1 / 8$ & 0.111 \\
\hline Skill & 8 & 1 & 0.889 \\
\hline
\end{tabular}

TABLE VI: THE PAIRWISE COMPARISON MATRIX FOR TEAMWORK AND TIME PUNCTUALITY SUB-CRITERIA

\begin{tabular}{|c|c|c|c|}
\hline & Teamwork & Time punctuality & Weights \\
\hline Teamwork & 1 & $1 / 7$ & 0.125 \\
\hline Time punctuality & 7 & 1 & 0.875 \\
\hline
\end{tabular}

Based on the weights obtained in Table III, it shows that the most important criteria is "outcome" followed by "Personal characteristics" as the second most important criteria. The third most important criteria are "teamwork and time punctuality". Followed by "capability", "experience and skill" and the least important is "competency".

TABLE VII: THE PAIRWISE COMPARISON MATRIX FOR PERSONAL

\begin{tabular}{|c|c|c|c|c|}
\hline & Attendance & $\begin{array}{c}\text { CHARACTERISTICS SUB-CRITERIA } \\
\text { Level of } \\
\text { adaptation to } \\
\text { change }\end{array}$ & $\begin{array}{c}\text { The degree } \\
\text { of loyalty } \\
\text { and } \\
\text { honesty }\end{array}$ & Weights \\
\hline Attendance & 1 & 5 & 6 & 0.726 \\
\hline $\begin{array}{c}\text { Level of } \\
\text { adaptation to } \\
\text { change }\end{array}$ & $1 / 5$ & 1 & 2 & 0.172 \\
\hline $\begin{array}{c}\text { The degree of } \\
\text { loyalty and } \\
\text { honesty }\end{array}$ & $1 / 6$ & $1 / 2$ & 1 & 0.102 \\
\hline
\end{tabular}

TABLE VIII: THE PAIRWISE COMPARISON MATRIX FOR OUTCOME SUB-CRITERIA

\begin{tabular}{|c|c|c|c|}
\hline & $\begin{array}{c}\text { Quality of } \\
\text { work }\end{array}$ & $\begin{array}{c}\text { Quantity of } \\
\text { work }\end{array}$ & Weights \\
\hline $\begin{array}{c}\text { Quality of } \\
\text { work }\end{array}$ & 1 & $1 / 4$ & 0.200 \\
\hline $\begin{array}{c}\text { Quantity of } \\
\text { work }\end{array}$ & 4 & 1 & 0.800 \\
\hline
\end{tabular}

TABLE IX: THE PAIRWISE COMPARISON MATRIX FOR CAPABILITY

\begin{tabular}{|c|c|c|c|}
\hline \multicolumn{4}{|c}{ SUB-CRITERIA } \\
\hline & $\begin{array}{c}\text { Working } \\
\text { ability }\end{array}$ & $\begin{array}{c}\text { Communication } \\
\text { ability }\end{array}$ & Weights \\
\hline Working ability & 1 & 7 & 0.875 \\
\hline $\begin{array}{c}\text { Communication } \\
\text { ability }\end{array}$ & $1 / 7$ & 1 & 0.125 \\
\hline
\end{tabular}

After obtaining the weights of each criteria and sub-criteria, the overall score of each alternative can be calculated using (3). Table X shows the AHP score for 17 alternatives.

\section{B. Computer Simulation}

Simulation is the process of building a model of a system experimenting with the model to obtain insight into the system's behavior in solving the decision problem. The idea behind simulation is to imitate a real system with a simulation model. After the simulation model is built, then the model is verified and validated to make sure that the model is free from logical errors and the model is the same as the real system. Next, the modeler can continue to do 'what if analysis?'. This enables the modeler to evaluate more than one alternative before choosing the best one. The advantages of simulation is it does not interfere with the real system, the experiment is done within the model and therefore will save costs. It will also save time because the effects of changes in variables over many months or years can be obtained by computer simulation in a short time. Besides, the simulation model can be controlled and repeated as many times as possible.

Simulation technique is widely used in food production systems. All conditions of the food production system can be modeled using simulation software. For example simulation is applied to improve the performance of the bakery production by rescheduling the production planning, thus it reduced the wasted time and the consumptions of energy [18]. A simulation model of a juice production line is applied in order to identify bottlenecks and to propose the improvement model that can meet current and future market demand for juice [19]. Simulation is used in solving a facility layout problem at the snack food manufacturing company. The proposed facility lay out are modeled using simulation software [20].

In this study, cassava-based snack food production system is modeled using ARENA software package version 14 [21]. Fig. 2 shows the layout of the production system. There are 
five processes involved in the production system of frying process and end at packaging process. cassava-based snack food, begins at peeling process, moves to washing process, continues on slicing process, moves to

TABLE X: THE AHP SCORE

\begin{tabular}{|c|c|c|c|c|c|c|}
\hline \multirow{2}{*}{$\begin{array}{c}\text { Alternative } \\
\text { (Operator) }\end{array}$} & \multicolumn{2}{|c|}{ Competency } & \multicolumn{2}{c|}{ Experience and skill } & \multicolumn{2}{c|}{ Teamwork and time punctuality } \\
\cline { 2 - 7 } & Training & $\begin{array}{c}\text { Educational } \\
\text { background }\end{array}$ & $\begin{array}{c}\text { Past experience in } \\
\text { other company } \\
\text { and experience in } \\
\text { the company }\end{array}$ & Skill & Teamwork & Time punctuality \\
\hline A1 & 0.059 & 0.059 & 0.075 & 0.013 & 0.059 & 0.054 \\
\hline A2 & 0.059 & 0.059 & 0.171 & 0.013 & 0.059 & 0.054 \\
\hline A3 & 0.059 & 0.059 & 0.083 & 0.013 & 0.059 & 0.054 \\
\hline A4 & 0.059 & 0.059 & 0.075 & 0.013 & 0.059 & 0.054 \\
\hline A5 & 0.059 & 0.059 & 0.143 & 0.238 & 0.059 & 0.054 \\
\hline A6 & 0.059 & 0.059 & 0.043 & 0.042 & 0.059 & 0.054 \\
\hline A7 & 0.059 & 0.059 & 0.015 & 0.024 & 0.059 & 0.054 \\
\hline A8 & 0.059 & 0.059 & 0.020 & 0.043 & 0.059 & 0.054 \\
\hline A9 & 0.059 & 0.059 & 0.139 & 0.055 & 0.059 & 0.043 \\
\hline A10 & 0.059 & 0.059 & 0.055 & 0.199 & 0.059 & 0.091 \\
\hline A11 & 0.059 & 0.059 & 0.020 & 0.035 & 0.059 & 0.052 \\
\hline A12 & 0.059 & 0.059 & 0.034 & 0.073 & 0.059 & 0.058 \\
\hline A13 & 0.059 & 0.059 & 0.007 & 0.006 & 0.059 & 0.038 \\
\hline A14 & 0.059 & 0.059 & 0.017 & 0.120 & 0.059 & 0.147 \\
\hline A15 & 0.059 & 0.059 & 0.024 & 0.021 & 0.059 & 0.047 \\
\hline A16 & 0.059 & 0.059 & 0.009 & 0.015 & 0.059 & 0.047 \\
\hline A17 & 0.059 & 0.059 & 0.070 & 0.077 & 0.059 & 0.047 \\
\hline
\end{tabular}

TABLE X: THE AHP SCORE (CONTINUED)

\begin{tabular}{|c|c|c|c|c|c|c|c|c|}
\hline \multirow[b]{2}{*}{$\begin{array}{l}\text { Alternative } \\
\text { (Operator) }\end{array}$} & \multicolumn{3}{|c|}{ Personal characteristics } & \multicolumn{2}{|c|}{ Outcome } & \multicolumn{2}{|c|}{ Capability } & \multirow[b]{2}{*}{$\begin{array}{c}\text { Overall } \\
\text { score }\end{array}$} \\
\hline & Attendance & $\begin{array}{l}\text { Level of } \\
\text { adaptation to } \\
\text { change }\end{array}$ & $\begin{array}{l}\text { The degree of } \\
\text { loyalty and honesty }\end{array}$ & $\begin{array}{l}\text { Quality of } \\
\text { work }\end{array}$ & $\begin{array}{l}\text { Quantity } \\
\text { of work }\end{array}$ & $\begin{array}{l}\text { Working } \\
\text { ability }\end{array}$ & $\begin{array}{l}\text { Communication } \\
\text { ability }\end{array}$ & \\
\hline A1 & 0.010 & 0.019 & 0.059 & 0.016 & 0.045 & 0.014 & 0.059 & 0.0347 \\
\hline A2 & 0.008 & 0.014 & 0.059 & 0.016 & 0.010 & 0.012 & 0.059 & 0.0227 \\
\hline A3 & 0.042 & 0.014 & 0.059 & 0.016 & 0.009 & 0.009 & 0.059 & 0.0258 \\
\hline A4 & 0.020 & 0.014 & 0.059 & 0.016 & 0.009 & 0.011 & 0.059 & 0.0232 \\
\hline A5 & 0.020 & 0.075 & 0.059 & 0.105 & 0.194 & 0.126 & 0.059 & 0.1206 \\
\hline A6 & 0.078 & 0.038 & 0.059 & 0.016 & 0.009 & 0.042 & 0.059 & 0.0364 \\
\hline A7 & 0.020 & 0.029 & 0.059 & 0.107 & 0.044 & 0.018 & 0.059 & 0.0444 \\
\hline A8 & 0.116 & 0.047 & 0.059 & 0.105 & 0.044 & 0.041 & 0.059 & 0.0609 \\
\hline A9 & 0.007 & 0.093 & 0.059 & 0.099 & 0.045 & 0.054 & 0.059 & 0.0492 \\
\hline A10 & 0.022 & 0.221 & 0.059 & 0.110 & 0.137 & 0.280 & 0.059 & 0.1284 \\
\hline A11 & 0.014 & 0.058 & 0.059 & 0.017 & 0.009 & 0.050 & 0.059 & 0.0290 \\
\hline A12 & 0.054 & 0.063 & 0.059 & 0.016 & 0.207 & 0.050 & 0.059 & 0.1046 \\
\hline A13 & 0.006 & 0.016 & 0.059 & 0.016 & 0.010 & 0.008 & 0.059 & 0.0183 \\
\hline A14 & 0.011 & 0.190 & 0.059 & 0.131 & 0.072 & 0.159 & 0.059 & 0.0955 \\
\hline A15 & 0.191 & 0.037 & 0.059 & 0.103 & 0.052 & 0.040 & 0.059 & 0.0707 \\
\hline A16 & 0.191 & 0.022 & 0.059 & 0.016 & 0.052 & 0.030 & 0.059 & 0.0612 \\
\hline A17 & 0.191 & 0.049 & 0.059 & 0.097 & 0.052 & 0.053 & 0.059 & 0.0750 \\
\hline
\end{tabular}

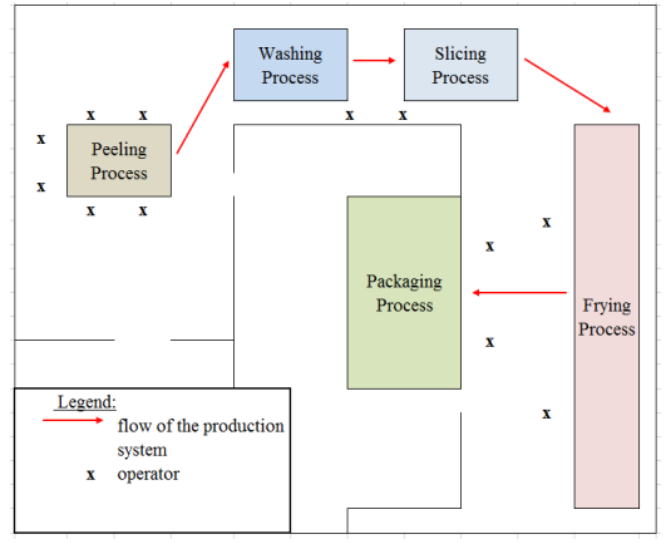

Fig. 2. Layout of the cassava-based snack food production system.

Currently, there are 12 operators involved in cassava-based snack food production system. Six operators are assigned to peeling process, two operators handled washing process and slicing process. There are two operators assigned to frying process and two operators to packaging process. The other five operators are entrusted to assist the production of other products and to replace operator who is on leave.

The data for the use of the model were collected on a daily basis during normal operating hours ( 8 hours). Input analyzer is used to analyze the data to obtain the appropriate distribution. All the distributions obtained from input analyzer are used in the model building of cassava-based snack food production system. Fig. 3 shows a part of the cassava-based snack food production system using ARENA software. After the model is developed, the model is run for 10 replications. The next step is to verify and to validate the model. Verification can be done using Little's formula [22]:

$$
\bar{N}=\lambda \bar{W}
$$




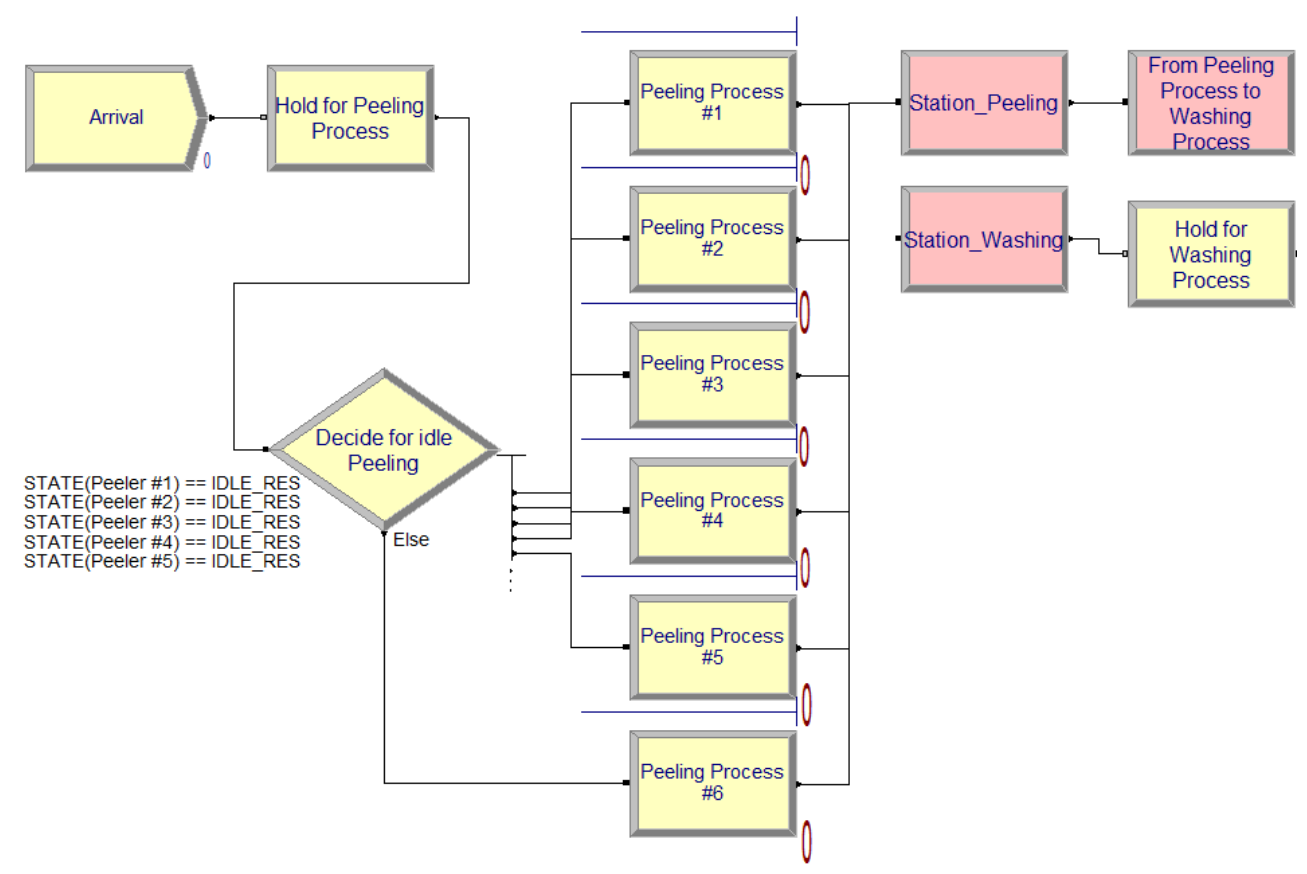

Fig. 3. A part of the cassava-based snack food production system using ARENA software.

The simulation output will be used in calculating the values. The entity in this production system refers to a basket of cassava consists of 15 pieces of cassava. $\bar{N}$ is the average number of baskets in the system which is 34.6203 baskets. $\lambda=0.93$ is the average rate of arrivals into the system $\left(\lambda=\frac{447}{480}\right) \cdot \bar{W}=37.4099$ minutes is the average time a basket of cassava spends in the system. $\lambda \bar{W}$ is therefore equals to 34.7912 , and therefore (4) is satisfied. Thus, the model is accepted as verified.

The comparison between simulated output and actual data is done to ensure the model is valid and can be calculated as follows.

Difference $(\%)=\frac{\mid \text { Simulation Output }- \text { Actual Data } \mid}{\text { Actual Data }} \times 100 \%$

The model is considered validated if the "Difference" percentage is less or equal to $10 \%$ [23].

Table XI-Table XII shows the "Difference" percentage for each process time, total number enter into the system and the total number out of the system. Since all values are not more than $10 \%$, it shows that the model is valid.

Once the model is verified and validated, further analysis can be done for better performance of the production system by improving the operator allocation decision.

TABLE XI: COMPARISON BETWEEN SIMULATED AND ACTUAL PROCESS TIME FOR EACH PROCESS

\begin{tabular}{|l|c|c|c|c|c|}
\cline { 2 - 6 } \multicolumn{1}{c|}{} & \multicolumn{5}{c|}{ Process } \\
\cline { 2 - 6 } \multicolumn{1}{c|}{} & Peeling & Washing & Slicing & Frying & Packaging \\
\hline $\begin{array}{l}\text { Simulation } \\
\text { Output } \\
\text { (minutes) }\end{array}$ & 2.7456 & 0.1231 & 0.8060 & 2.4428 & 0.8586 \\
\hline $\begin{array}{l}\text { Actual Data } \\
\text { (minutes) }\end{array}$ & 2.7462 & 0.1208 & 0.8095 & 2.4333 & 0.8966 \\
\hline $\begin{array}{l}\text { Difference } \\
(\%)\end{array}$ & 0.022 & 1.904 & 0.432 & 0.390 & 4.238 \\
\hline
\end{tabular}

The production system of cassava-based snack food has one production line with 17 operators in total. The supervisor of the company evaluated all operators using the AHP method based on several criteria and sub-criteria (refer to Table III-Table IX). The overall ranking of operators is presented in Table XIII. Operator A10 is in the first rank. After evaluating the performance of the operators, then the operators are divided into 4 groups. The operators are divided into four groups according to the performance score obtained from AHP. Group 1 for good performance, group 2 for average performance, group 3 and group 4 refer to satisfactory and poor performance, respectively. The operators in group 1 are the top four in the rank, they are operators A10, A5, A12 and A14. Followed by operators A17, A15, A16 and A8 are in group 2. The operators in group 3 are $\mathrm{A} 9, \mathrm{~A} 7, \mathrm{~A} 6$ and $\mathrm{A} 1$.

TABLE XII: COMPARISON BETWEEN SIMULATED AND ACTUAL DATA ON TOTAL BASKETS ENTER INTO THE SYSTEM (NUMBER IN) AND TOTAL

\begin{tabular}{|l|c|c|}
\multicolumn{1}{c|}{ PRODUCTION (NUMBER OUT) } \\
\cline { 2 - 3 } \multicolumn{1}{c|}{} & \multicolumn{2}{c|}{ Phase } \\
\cline { 2 - 3 } & $\begin{array}{c}\text { Number } \\
\text { in (per } \\
\text { basket) }\end{array}$ & $\begin{array}{c}\text { Number } \\
\text { out (per } \\
\text { packet) }\end{array}$ \\
\hline Simulation Output (units) & 447 & 385 \\
\hline Actual Data (units) & 432 & 360 \\
\hline Difference (\%) & 3.472 & 6.944 \\
\hline
\end{tabular}

\section{RESULTS AND DISCUSSIONS}

The remaining operators are in group 4. All five operators in group 4 are in the lowest ranking. In operator allocation decision, operators in group 4 are not included in the improvement models. This is because the management of the company should give appropriate training to them. Thus, it will help the operators work more efficiently.

Next step is to allocate operator to each process according to the operators' performance score obtained from AHP. Table XIV displays the major task of each operator in the production system of cassava-based snack food. Based on the data obtained during normal operating hours, the process 
time in each process can be classified into four different groups regarding the performance of operators. Group 1, group 2, group 3 and group 4 refer to operators' with good performance, average performance, satisfactory performance and poor performance, respectively. Table XV shows the process time distribution at each process based on group classification.

TABLE XIII: THE OVERALL RANKING OF OPERATORS

\begin{tabular}{|c|c|c|}
\hline Alternative (Operator) & Score & Rank \\
\hline A10 & 0.1284 & 1 \\
\hline A5 & 0.1206 & 2 \\
\hline A12 & 0.1046 & 3 \\
\hline A14 & 0.0955 & 4 \\
\hline A17 & 0.0750 & 5 \\
\hline A15 & 0.0707 & 6 \\
\hline A16 & 0.0612 & 7 \\
\hline A8 & 0.0609 & 8 \\
\hline A9 & 0.0492 & 9 \\
\hline A7 & 0.0444 & 10 \\
\hline A6 & 0.0364 & 11 \\
\hline A1 & 0.0347 & 12 \\
\hline A11 & 0.0290 & 13 \\
\hline A3 & 0.0258 & 14 \\
\hline A4 & 0.0232 & 15 \\
\hline A2 & 0.0227 & 16 \\
\hline A13 & 0.0183 & 17 \\
\hline
\end{tabular}

In order to analyze the impact of operators' performance to the operator allocation decision, two models have been developed. The number of operators at each process is the same as the Actual Model. Six operators are allocated to peeling process, two operators in charge of washing and slicing process. The operators in charge of washing and slicing process are the same operators. At the frying process, there are two operators and also two operators are handling the packaging process.

The first model is Improvement Model 1. This model represents the operator allocation based on operators' performance score with the consideration of operators' major tasks given by the company. The operator allocation decision for Improvement Model 1 is shown in Table XVI. In Improvement Model 2 the operators are allocated with the assumption the performance of operators had improved and their processes time distribution is referred to operators' with good performance (group 1) and operators' with average performance (group 2).

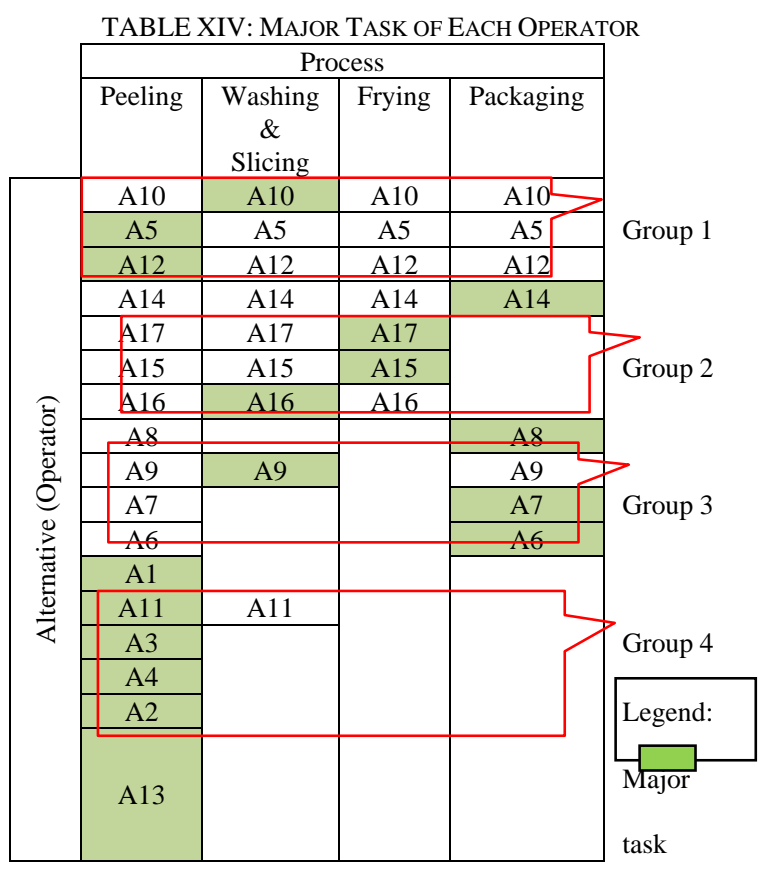

In the Actual Model, all operators were assumed to have the same level of performance. In that case all processes time distribution at each process for each operator was similar. In Improvement Model 1 and Improvement Model 2 the process time distribution at each process for each operator varied because operators' performance level is different. The process time distribution at each process for Actual Model, Improvement Model 1 and Improvement Model 2 is presented in Table XVII.

TABLE XV: PROCESS TIME DistRIBUTION AT EACH PROCESS BASED ON GROUP CLASSIFICATION

\begin{tabular}{|c|l|l|l|l|}
\hline \multirow{2}{*}{$\begin{array}{c}\text { Process time } \\
\text { (seconds })\end{array}$} & \multicolumn{3}{|c|}{ Group } \\
\cline { 2 - 5 } & \multicolumn{1}{|c|}{1} & \multicolumn{1}{|c|}{2} & \multicolumn{1}{|c|}{3} \\
\hline Peeling & $59.5+31 * \operatorname{BETA}(0.281,0.328)$ & $105+31 * \operatorname{BETA}(0.27,0.296)$ & $150+16 * \mathrm{BETA}(0.0445,0.048)$ & $180+\mathrm{EXPO}(91.5)$ \\
\hline Washing & TRIA $(3,4,6)$ & TRIA $(6.2,6.25,6.8)$ & TRIA $(6.5,8,9.5)$ \\
\hline Slicing & TRIA $(15,22.5,30)$ & TRIA $(35,35.7,41.9)$ & TRIA $(45,45.8,53)$ & TRIA(10,12.3,13) \\
\hline Frying & TRIA $(130.5,132,134.5)$ & TRIA $(135.5,139,143.5)$ & TRIA $(144.5,147,156.5)$ \\
\hline Packaging & TRIA $(43,43.5,44)$ & TRIA $(46.5,47,48.5)$ & TRIA $(53.5,60,66.5)$ \\
\hline
\end{tabular}

TABLE XVI: OPERATOR AllocATION BASED ON OPERATORS’ PERFORMANCE SCORE AND MAJOR TASK FOR IMPROVEMENT MODEL 1

\begin{tabular}{|c|c|c|c|c|c|}
\cline { 2 - 5 } \multicolumn{1}{c|}{} & \multicolumn{4}{|c|}{ Process } \\
\cline { 2 - 6 } \multicolumn{1}{c|}{ Alternative } & Peeling & Washing & Slicing & Frying & Packaging \\
(Operator) & 2) A12 & 1) A10 & 1) A17 & 1) A14 \\
& 3) A9 & 2) A16 & 2) A15 & 2) A8 \\
& 4) A7 & & & \\
& 5) A6 & & & \\
& 6) A1 & & & \\
\hline \hline
\end{tabular}

The Improvement Model 1 and Improvement Model 2 are run for 10 replications. Referring to Table XVIII, the Improvement Model 1 and Improvement Model 2 have improved compared to Actual Model according to results obtained from computer simulation.

The comparison among these three models are made based on total production, average total production time, average total wait times, average number of baskets in the system and average operator utilization. The Improvement Model 1 and Improvement Model 2 show that the number of total production had increased. The average total production time, average total wait times, average number of baskets in the 
system and average operator utilization were reduced. Based on the results obtained from computer simulation, it demonstrates that if the performance of operators are included in the operator allocation decision it will improve the performance of the production system.

TABLE XVII: Process TIME DisTRIBUTION AT EACH PROCESS FOR ACTUAL MODEL, IMPROVEMENT MODEL 1 AND IMPROVEMENT MODEL 2

\begin{tabular}{|c|c|c|c|}
\hline $\begin{array}{l}\text { Process time } \\
\text { (seconds) }\end{array}$ & Actual Model & Improvement Model 1 & Improvement Model 2 \\
\hline Peeling & $60+\mathrm{EXPO}(150)$ & $\begin{array}{l}\text { 1) } 59.5+31 * \operatorname{BETA}(0.281,0.328) \\
\text { 2) } 59.5+31 * \operatorname{BETA}(0.281,0.328) \\
\text { 3) } 150+16 * \operatorname{BETA}(0.0445,0.048) \\
\text { 4) } 150+16 * \operatorname{BETA}(0.0445,0.048) \\
\text { 5) } 150+16 * \operatorname{BETA}(0.0445,0.048) \\
\text { 6) } 150+16 * \operatorname{BETA}(0.0445,0.048)\end{array}$ & $\begin{array}{l}\text { 1) } 59.5+31 * \operatorname{BETA}(0.281,0.328) \\
\text { 2) } 59.5+31 * \operatorname{BETA}(0.281,0.328) \\
\text { 3) } 105+31 * \operatorname{BETA}(0.27,0.296) \\
\text { 4) } 105+31 * \operatorname{BETA}(0.27,0.296) \\
\text { 5) } 150+16 * \operatorname{BETA}(0.0445,0.048) \\
\text { 6) } 150+16 * \operatorname{BETA}(0.0445,0.048)\end{array}$ \\
\hline Washing & $4+9 * \operatorname{BETA}(0.519,0.917)$ & $\begin{array}{l}\text { 1) } \operatorname{TRIA}(3,4,6) \\
\text { 2) } \operatorname{TRIA}(6.2,6.25,6.8)\end{array}$ & $\begin{array}{l}\text { 1) } \operatorname{TRIA}(3,4,6) \\
\text { 2) } \operatorname{TRIA}(3,4,6) \\
\end{array}$ \\
\hline Slicing & TRIA( $(15,40.7,90)$ & $\begin{array}{l}\text { 1) } \operatorname{TRIA}(15,22.5,30) \\
\text { 2) } \operatorname{TRIA}(35,35.7,41.9)\end{array}$ & $\begin{array}{l}\text { 1) } \operatorname{TRIA}(15,22.5,30) \\
\text { 2) } \operatorname{TRIA}(15,22.5,30)\end{array}$ \\
\hline Frying & $132+\operatorname{ERLA}(14.5,1)$ & $\begin{array}{l}\text { 1) } \operatorname{TRIA}(135.5,139,143.5) \\
\text { 2) } \operatorname{TRIA}(135.5,139,143.5) \\
\end{array}$ & $\begin{array}{l}\text { 1) TRIA(130.5,132,134.5) } \\
\text { 2) TRIA( }(130.5,132,134.5) \\
\end{array}$ \\
\hline Packaging & $42.5+\operatorname{LOGN}(14.7,45.6)$ & $\begin{array}{l}\text { 1) } \operatorname{TRIA}(43,43.5,44) \\
\text { 2) } \operatorname{TRIA}(46.5,47,48.5)\end{array}$ & $\begin{array}{l}\text { 1) } \operatorname{TRIA}(43,43.5,44) \\
\text { 2) } \operatorname{TRIA}(43,43.5,44)\end{array}$ \\
\hline
\end{tabular}

TABLE XVIII: COMPARISON BETWEen ACTUAL MODEL, IMPROVEMENT MODEL 1 AND IMPROVEMENT MODEL 2

\begin{tabular}{|c|c|c|c|c|c|}
\hline & $\begin{array}{c}\text { Total Production } \\
\text { (units) }\end{array}$ & $\begin{array}{c}\text { Average total production } \\
\text { time (minutes) }\end{array}$ & $\begin{array}{c}\text { Average total wait } \\
\text { times (minutes) }\end{array}$ & $\begin{array}{c}\text { Average number of baskets } \\
\text { in the system (units) }\end{array}$ & $\begin{array}{c}\text { Average operator } \\
\text { utilization (\%) }\end{array}$ \\
\hline Actual model & 385 & 37.4099 & 28.7445 & 34 & 50.67 \\
\hline $\begin{array}{c}\text { Improvement } \\
\text { Model 1 }\end{array}$ & 405 & 34.0951 & 26.6543 & 43 \\
\hline $\begin{array}{c}\text { Improvement } \\
\text { Model 2 }\end{array}$ & 422 & 24.7867 & 17.8129 & 40 \\
\hline
\end{tabular}

\section{CONCLUSION}

An integration of AHP and computer simulation has been demonstrated in analyzing the impact of production system's performance if operators' performance is considered in the operator allocation decision. AHP is identified as the appropriate method in evaluating operators' performance because it is easy to comprehend, systematic and inclusive, especially when applied to SME's food manufacturing company. Computer simulation is observed as a relevant method to use because it is flexible in designing the operator allocation models and in generating output. In the context of this study, it is agreed that operators' performance had influenced the production system's performance. For future improvement of this study, several improvement models with different combination of processes time distribution according to operators' performance will be identified. Later, an optimization technique will be used to determine the optimal operator allocation.

\section{REFERENCES}

[1] Productivity Report 2012/2013, Malaysia Productivity Corporation, 2013, p. 4.

[2] T. Majozi and X. X. Zhu, "A combined fuzzy set theory and MILP approach in integration of planning and scheduling of batch plants-Personnel evaluation and allocation," Computers and Chemical Engineering, vol. 29, pp. 2029-2047, August 15, 2005.

[3] K. K. Krishnan, S. Mirzaei, and S. M. S. Pachaimuthu, "Risk based worker allocation," Journal of Supply Chain and Operations Management, vol. 10, no. 2, pp. 139-162, 2012.

[4] T. Ertay and D. Ruan, "Data envelopment analysis based decision model for optimal operator allocation in CMS," European Journal of Operational Research, vol. 164, no. 3, pp. 800-810, 2005.

[5] T. Yang, M.-C. Chen, and C.-C. Hung, "Multiple attribute decision-making methods for the dynamic operator allocation problem," Mathematics and Computers in Simulation, vol. 73, no. 5, pp. 285-299, 2007.
[6] A. Azadeh, M. Anvari, B. Ziaei, and K. Sadeghi, "An integrated fuzzy DEA-fuzzy C-means simulation for optimization of operator allocation in cellular manufacturing systems," The International Journal of Advanced Manufacturing Technology, vol. 46, pp. 361-375, Jan. 2010.

[7] C. G. Sen and G. Cinar, "Evaluation and Pre-allocation of Operators with Multiple Skills: A Combined Fuzzy AHP and Max-min Approach," Expert Systems with Applications, vol. 37, no. 3, pp. 2043-2053, 2010.

[8] T. L. Saaty, "How to make a decision: the analytic hierarchy process," European Journal of Operational Research, vol. 48, no. 1, pp. 9-26, 1990.

[9] R. Islam and M. Rasad, "Employee Performance Evaluation by the AHP: A Case Study," Asia Pacific Management, vol. 11, no. 3, pp. 163-176, 2006.

[10] D. Lu and J. Yu, "Research on the Performance Evaluation of Production Line Workers from the Perspective of Strategy Human Resource Management," in Proc. International Conference on Management and Service Science 2009, 2009, pp. 1-4.

[11] Z. Güngör, G. Serhadlığlu, and S. E. Kesen, "A fuzzy AHP approach to personnel selection problem," Applied Soft Computing, vol. 9, no. 2, pp. 641-646, 2009.

[12] T. L. Saaty and L. G. Vargas, Models, Methods, Concepts \& Applications of the Analytic Hierarchy Process, $2^{\text {nd }}$ Edition, Springer New York Heidelberg Dordrecht London, 2012, ch. 1, p. 9.

[13] Expert Choice User's Guide, Expert Choice, Inc., Pittsburgh, PA, 2004.

[14] C. T. Chen, Y. C. Hwang, and W. Z. Hung, "Applying multiple linguistic PROMETHEE method for personnel evaluation and selection," in Proc. IEEE International Conference on Industrial Engineering and Engineering Management, 2009, pp. 1312-1316.

[15] A. Kelemenis and D. Askounis, "A new TOPSIS-based multi-criteria approach to personnel selection," Expert Systems with Applications, vol. 37, no. 7, pp. 4999-5008, 2010.

[16] S. Ahmad and A. D. Silong, "Keberkesanan Penilaian Prestasi Kerja di Kalangan Kakitangan Perkeranian (The effectiveness of performance appraisal among clerical staff)," Pertanika Journal of Social Sciences \& Humanities, vol. 4, no. 1, pp. 55-63, 1996.

[17] D. L. Deadrick, N. Bennett, and C. J. Russell, "Using hierarchical linear modeling to examine dynamic performance criteria over time," Journal of Management, vol. 23, no. 6, pp. 745-757, 1997.

[18] F. Hecker, W. Hussein, and T. Becker, "Analysis and optimization of a bakery production line using ARENA," International Journal of Simulation Modelling, vol. 9, no. 4, pp. 208-216, 2010.

[19] A. Ur-Rehman et al., "Modeling of juice production line using simulation," in Proc. IEEE 17th International Conference In Industrial 
Engineering and Engineering Management (IE\&EM), 2010, pp. $1555-1559$.

[20] A. Norani, S. Nurulzulaiha, J. Norzarin, and K. Isahak, "Using simulation to solve facility layout for food industry at XYZ company," in Proc. IEEE Symposium on Humanities, Science and Engineering Research, 2012, pp. 647-652.

[21] Arena ® Simulation Software User's Guide, Rockwell Automation, Inc. , Pittsburgh, PA, 2012

[22] T. Altiok and B. Melamed, Simulation Modeling and Analysis with Arena, Academic Press, 2007, pp. 148.

[23] D. R. Anderson, D. J. Sweeney, and T. A. Williams, An Introduction to Management Science, Ohio: Thomson South-Western, 2005, p. 619.

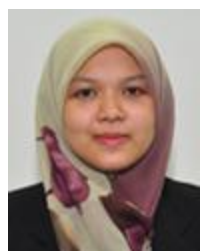

Ruzanita Mat Rani is a PhD student at the School of Mathematical Sciences, Universiti Kebangsaan Malaysia. She received her B. Sc. in mathematics from Universiti Putra Malaysia and M. Sc. in decision sciences from Universiti Utara Malaysia. Her research interests include simulation, data envelopment analysis and multi criteria decision making.

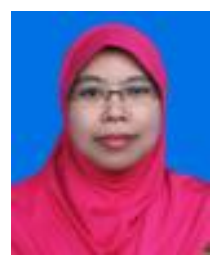

Wan Rosmanira Ismail is a senior lecturer at the School of Mathematical Sciences, Faculty of Science and Technology, Universiti Kebangsaan Malaysia. She obtained her $\mathrm{PhD}$ in operational research from Loughborough University, UK in the year 2000. Her research interests include mathematical modeling, scheduling and routing, timetabling, efficiency and multi criteria decision making.

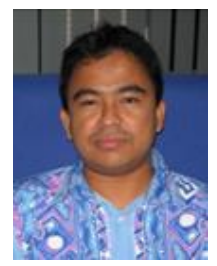

Mohd Nizam Ab. Rahman is an associate professor in the Department of Mechanical and Materials Engineering, Faculty of Engineering \& Built Environment, Universiti Kebangsaan Malaysia. He received his $\mathrm{PhD}$ in quality and operations management, University of Nottingham, UK in the year 2004. His research interests include engineering sciences, manufacturing and production engineering, quality, operations management and product life cycle. 